\title{
ITO ドライエッチングとパターニング技術
}

伴厚 志*

\section{Dry Etching of ITO Film and Patterning Technology}

Atsushi BAN*

Key Words : ITO, Dry Etching, RIE, Plasma, TFT LCD

LCD の大型・高精細化に伴い, ITO膜も加工精度に優れるドライエッチング化に向っている。 ITO ドライエッチング技術の現状をウエットエッチングと比較しながら紹介する。

\section{1.はじめに}

近年，液晶ディスプレイ(LCD)は，CRTでは実現て きない薄型・軽量・低消費電力を武器に, ノート PC・ モニター・携帯情報端末の分野で華々しい躍進を続けて いる。また, 最近では大型 TV 市場への展開も始まり， 夢の壁掛けテレビが現実のものとなっている。このよう な中，LCD の新たな市場として CRTでは技術的に実 現が難しいとされる高精細ディスプレイが注目され始め ている。高精細ディスプレイでは, 画面の構成単位であ る絵素のサイズが小さくなるため, 表面輝度を決めてい るバックライト光の透過率を確保するために, 素子の加 工精度を向上させ，絵素電極であるITOの領域を広く とる必要がある。具体的には，走査線・信号線といった 金属配線の線幅を細くし，また絵素電極であるITO と 各配線とのギャップを狭くすることが要求される。これ ら各種薄膜の加工には, 加工精度と歩留まりの観点から ドライエッチング法が一般的に有利とされており，液晶 業界においても半導体層, 金属層, および絶縁膜の加工 にはドライエッチング法が広く採用されている。ITO ドライエッチングについては技術課題も多く，末だウ エットエッチングが主流となっているのが現状であるが, 今後の大型・高精細化への流れ, 廃液処理等の環境問題 を考える場合，ITO のドライエッチング化の早期展開 が強く期待されていると言える。

*シャープ秼液晶開発本部 液晶研究所（テ632-0004 奈良県天 理市櫟本町 2613-1)

Sharp Corp. LCD Development Group LCD Lab. (2613-1, Ichinomoto-cho, Tenri-shi, Nara 632-0004)

\section{2. 薄膜トランジスタ(TFT) 基板}

\section{1 TFT 基板構造}

図 1 に一般的な絵素構造の断面図を示す。図 1 (a)は主 にアモルファスシリコン $(\mathrm{a}-\mathrm{Si}) \mathrm{TFT}$ 基板に採用されて いる構造であり, 絵素電極 ITO は信号線と同層のゲー 卜絶緑膜上に形成されている。信号線と絵素電極の吵間 からバックライト光が漏れるのを防ぐため, カラーフィ

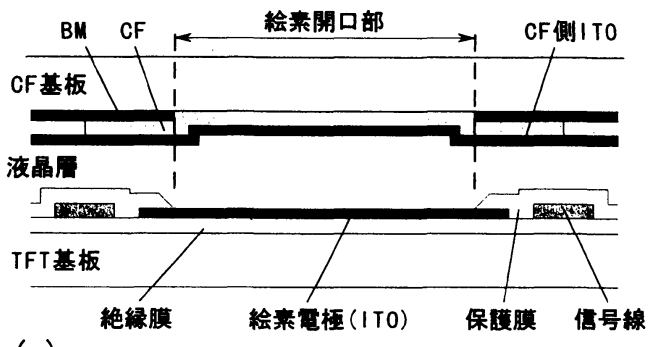

(a)

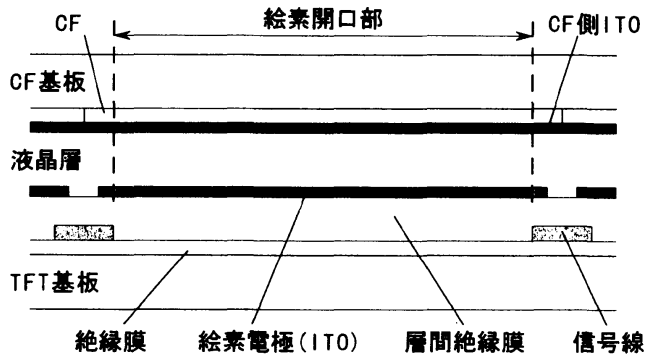

図 1 絵素断面構造 
ルタ $(\mathrm{CF})$ 基板側に遮光膜 $(\mathrm{BM})$ を形成している。開口 部を大きくとるためには信号線と絵素電極の間隔を可能 な限り狭くする必要がある。図 1 (b)は一部のa-Si TFT 基板とポリシリコン TFT 基板に採用されている構造で あり, 絵素電極 ITOは樹脂材料からなる層問絶縁膜上 に形成されている。この構造では CF 基板に $\mathrm{BM}$ が不 要のため高い開口率を得ることができる ${ }^{11,2) 。}$

ITO 膜エッチングへの要求項目として, (1)エッチン グ速度, (2)加工精度, (3)下地へのダメージ,などが上げ られる。(1)については, 絵素電極に用いられている ITO の膜厚は透過率の関係で一般的に $100 \mathrm{~nm} \sim 200 \mathrm{~nm}$ 程度であるため, 装置の処理能力を考慮した場合 200 $\mathrm{nm} / \mathrm{min}$ 程度が必要となるであろう。(2)については，今 後の大型基板 (1 m 角)での高精細パネル製造を考える場 合, 基板面内で $0.5 \mu \mathrm{m}$ 以内が要求されるはずである。 (3)については, 歩留まりと素子特性の維持から $\mathrm{Al}$ 等の 金属配線と, $\mathrm{SiN}_{\mathrm{x}}$ 等の絶縁膜との大きなエッチングの 選択性が必要となる。また, トランジス夕特性への影響 の無いエッチングが要求される。

\section{2 エッチング技術の現状と課題}

ITO のエッチング方法としては $\mathrm{HI}, \mathrm{HBr}, \mathrm{HCl}+$ $\mathrm{FeCl}_{3}$ 等の溶液を用いたウエットエッチングと, ハロゲ ンガス系拉よび有機ガス系を用いたドライエッチングが ある。実際の生産装置としては, ドライエッチングプロ セスが充分に成熟していないこともありウエットエッチ ングが主流となっている。しかし，ウエットエッチング にも課題は多く, 例えばエッチング速度 $(50 \mathrm{~nm} / \mathrm{min}$ 程 度), 加工精度, $\mathrm{Al}$ 配線の腐食などのプロセス上の闍題 と, 廃液処理等の設備・環境の問題が上げられる。中で も, 今後の大型・高精細化にとって特に大きな問題とな るのが加工精度である。加丁精度が取り難いとされる原 因として，大きく2つ上げることができる。1つは， ITOのエッチングが結晶粒界面から進むため, 結果と してレジストとの界面にエッチャントが染み込みアン ダーカットが大きく入ることである。またこのことは 結晶粒の粒状の残渣が残りやすい原因ともなっている。 図 2 に $\mathrm{HCl}+\mathrm{FeCl}_{3}$ 系でエッチングしたITOの断面 SEM 写真を示す。

2つ目は, エッチング速度が ITO 膜の結晶性に大き く左右されることである ${ }^{3)}$ 。実際のプロセスでは, 成膜 装置の問題や下地パターンの違いにより,ガラス基板面 内のITO 結晶性に大きなバラツキが生じる。このため, エッチング時間は最もエッチング速度が遅い部分に合わ せる必要があり，エッチング速度が速い部分はかなりの 時間オーバーエッチングされることになる。1つ目の問 題と合わさり, 基板面内で加工精度に大きなバラッキが 生じる結果となる。図 3 にオーバーエッチング量とパ ターンシフトの関係を示す12) ウェットエッチングでは

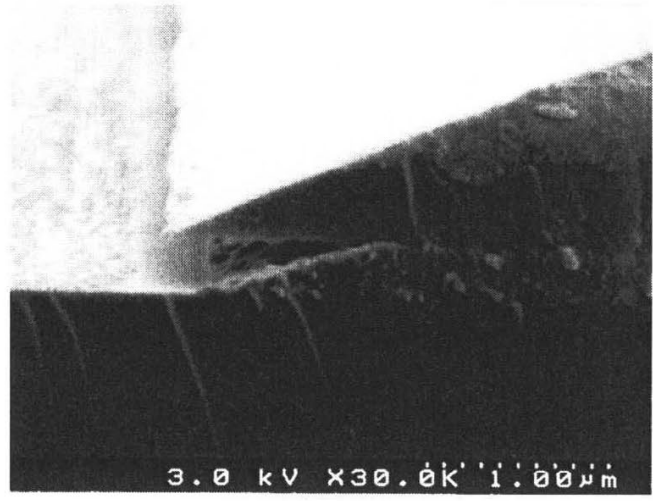

(a) エッチング後

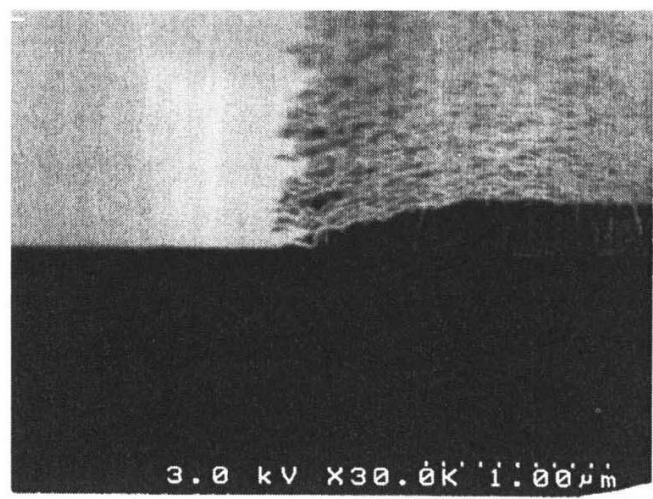

（b）レジストはく離後

图 2 ITO ウエットエッチング形状

膜厚 : $300 \mathrm{~nm}$, エッチャント : $\mathrm{HCL}+\mathrm{FeCL}_{3}$

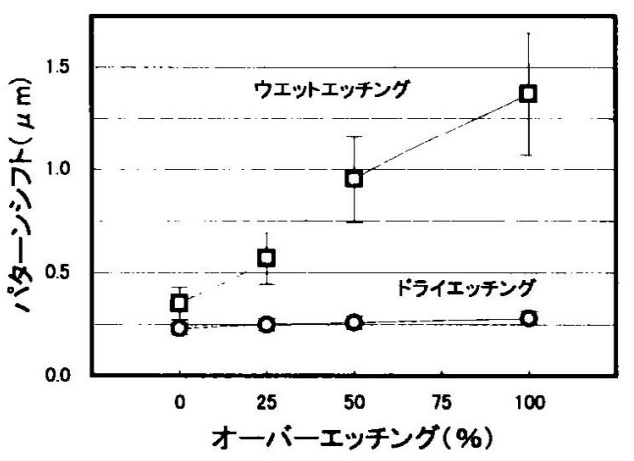

図3パターンシフトのエッチング量依存性

パターンシフトおよびバラツキが大きいのに対し，ドラ イエッチングでは非常に小さいことがわかる。これはド ライエッチングが結晶性に左右されにくく，またアンダ カットが小さいという特性が要因となっている。 


\section{3.ドライエッチング技術}

ドライエッチングによるITO の加工については，ウ エットエッチングに対する優位性から，近年急速に検討 が進んでいる。具体的な特徵として, エッチング速度が 大きく取れる可能性があること, 加工精度が優れている こと(コントロールできること)，Al配線の腐食が制御 できることなどが上げられる。以下にドライエッチング 技術の現状についてまとめる。

\section{1 ドライエッチング装置}

図4に一般的に用いられている平行平板型の反応性イ オンエッチング(RIE : Reactive Ion Etching)装置の構 造図を示す。ドライエッチングの詳しいメカニズムにつ いては専門書に委ねるとし，ここではメカニズムの概要 について説明する。反応室内は通常 $10^{-5}$ Torr 程度の高 真空に保持されており，予備真空室より被エッチング基 板が搬送され下部電極上に設置された後, 反応性ガスが 20～200 mTorr 程度に導入調圧される。そして，下部 電極に高周波(一般的に $13.56 \mathrm{MHz}$ )を印加し反応性ガ スをプラズマ放電させる。このプラズマ放電により生じ た電子, 反応性イオン, ラジカルのうち移動度の大きな 電子は高周波に追随し下部電極に入射する。その結果下 部電極の表層にシースと呼ばれる急峻な電位勾配, つま り陰極降下 $(\mathrm{Vdc})$ が発生する。このシースにより加速さ れた反応性イオンが被エッチング基板に入射するため, アンダーカットの少ない異方性エッチングが可能となる。 さらに, この反応性イオンの基板への入射は，イオン衝 撃(Ion Bombardment) として基板温度を上昇させる効 果があり, 被エッチング物とラジカルとの反応を活性化 させる働きを持つ。これらエッチングの異方性, イオン 衝撃は圧力，高周波電力等の条件で制御することができ，

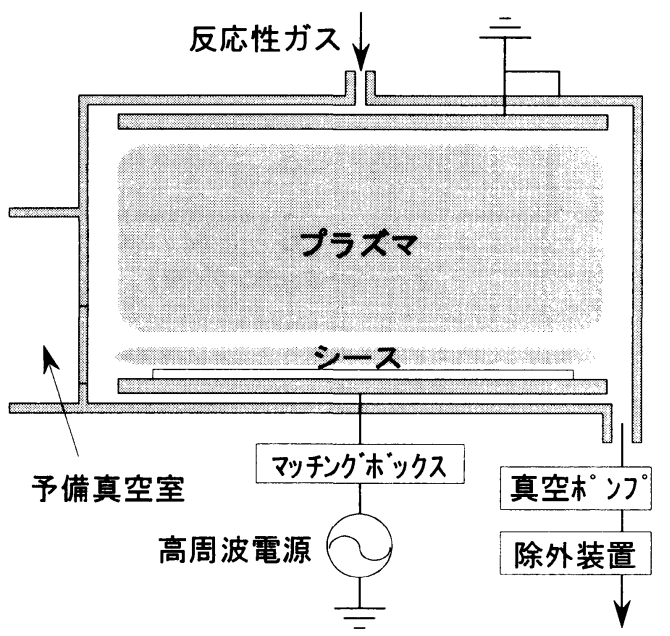

エッチング速度，テーパ形状，下地ダメージ等をある程 度コントロールすることが可能となる。

\section{2 エッチングメカニズム}

ITO 膜のエッチングに使用される反応性ガスとして,

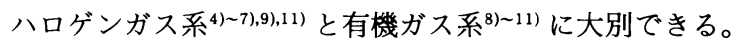
表 1 に一般的に検討されている反応性ガスをまとめる。 これらの反応性ガスと In と Sn の酸化物であるITO と の反応過程について図 5 に該略を示す ${ }^{10), 11)}$ 。反応室内に 導入された反応性ガスは，プラズマ放電により分解され, 多くは中性ラジカル $\left(^{*}\right)$ となり, また一部はイオン化さ れる。プラズマにより生成された $\mathrm{H}^{*}, \mathrm{C}^{*}, \mathrm{H}^{+}, \mathrm{C}^{+}$等 の中性ラジカル・イオンによりITO の還元が進む。こ のときイオンはシースにより加速され基板に衝突し， ITO の物理的な分解に寄与している。また同時に, こ のイオン衝撃は基板温度の上昇を促し, 化学的反応の活 性化に寄与している。より大きなイオン衝撃の効果を得

表 1 反応性ガス

\begin{tabular}{|l|l|}
\hline ハロゲンガス系 & 有機ガス系 \\
\hline $\mathrm{HCl}, \mathrm{HBr}, \mathrm{HI}$ & $\mathrm{CH}_{4}, \mathrm{CH}_{3} \mathrm{OH}$ \\
$\mathrm{Cl}$ & $\mathrm{C}_{2} \mathrm{H}_{5} \mathrm{OH}$ \\
$($ 添加ガス) & (添加ガス) \\
$\mathrm{Ar}, \mathrm{N}_{2}$ & $\mathrm{H}_{2}, \mathrm{HCl}$ \\
\hline
\end{tabular}

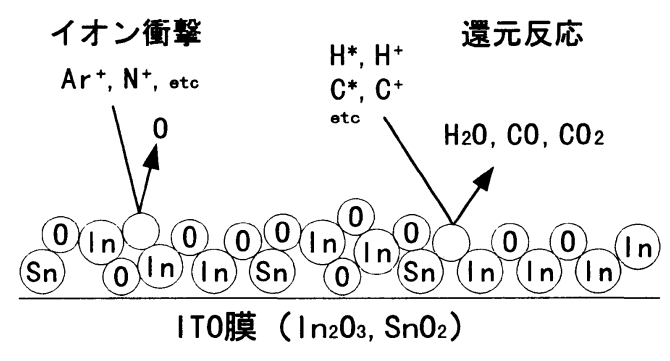

a) 酸化物の還元 ·分解

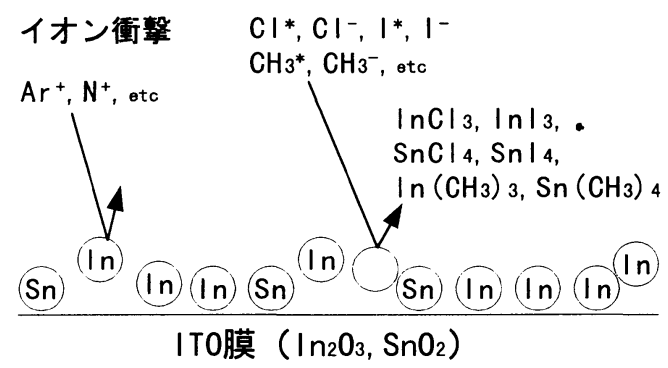

b) In, Snとの反応 


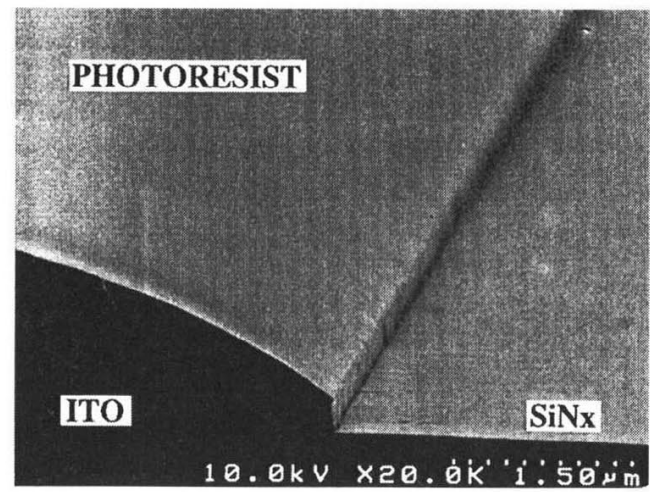

(a) エッチング後

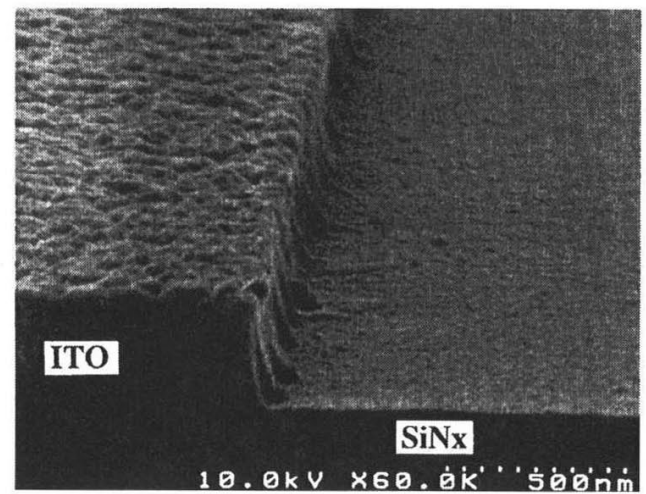

（b）レジストはく離後

図6 ITO ドライエッチング形状

膜厚 : $300 \mathrm{~nm}$, 反応性ガス : HI

るために，反応性ガスの中に $\mathrm{Ar}$ 等の不活性ガスを添加 させることも一般的に行われている8)100。次に, 還元・ 分解により生じた $\mathrm{In}, \mathrm{Sn} と \mathrm{Cl}^{*}, \mathrm{CH}_{3}{ }^{*}, \mathrm{Cl}^{-}, \mathrm{CH}_{3}{ }^{-}$等 の中性ラジカル・イオンが反応し, 揮発性の化合物とな り基板表面より除去される。図 6 に HI ガスを用いて エッチングしたITOの断面 SEM 写真を示す。(a)はド ライエッチング直後の形状，(b)はレジストをはく離した 後の形状である。 RIEにより, 異方性の強いエッチン グが行われていることがわかる。

\section{3 ドライエッチングの現状と課題}

\section{3. 1 エッチング速度}

RIE 装置を用いたものとしては，ハロダンガス系で $100 \sim 150 \mathrm{~nm} / \mathrm{min}$ 程度, 有機がス系で $50 \sim 100 \mathrm{~nm} / \mathrm{min}$ 程度が報告されている5 との主な化合物である $\mathrm{InI}_{3}$ の蒸気圧が他のガス系より も高いことから，大きなエッチング速度が得られること で注目されている。図7にHIガスを用いた反心性イオ ンエッチングの評価結果の一例を示す ${ }^{22}$ 。この詊価結果 からは，ドライエッチング压力が高真空であるほど高い エッチング速度がえられていることがわかる。この傾向

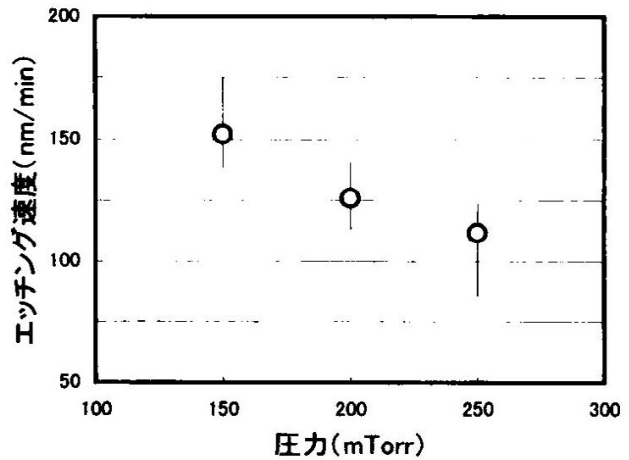

图 7 エッチング速度の圧力依存性

反応性ガス: $\mathrm{HI}$, 電力密度 $: 1.4 \mathrm{~W} / \mathrm{cm}^{2}$

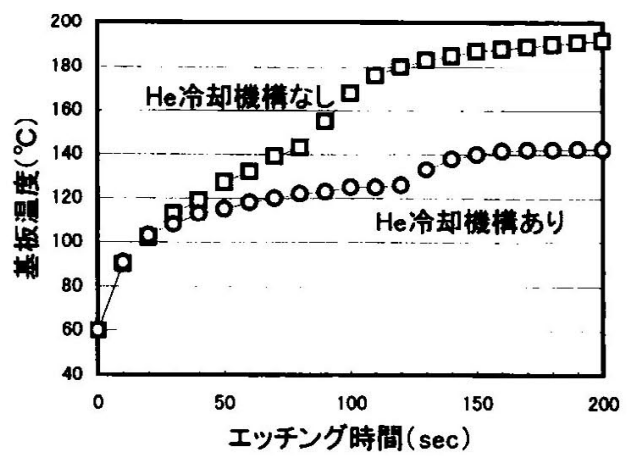

图 $8 \mathrm{He}$ 冷却機構の効果

$\mathrm{CF}_{4}+\mathrm{O}_{2}$ ガスによる $\mathrm{Ta}$ 膜のエッチング

は他のハロゲンガスおよび有機ガス系でも同様である。 これは，高真空であるほどシース部での電極降下(Vdc) が大きくなり，その結果イオン衝撃が増大し，ITOの 物理的分解と基板温度上昇による化学反応と揮発性化合 物の蒸発除去が促進されるためである。このように大き なエッチング速度を得るためには，大きな供給電力と高 真空によりイオン性を強め, 物理的分解と基板温度の上 笔を促す必要がある ${ }^{8,111}$ 。しかし，基板温度がレジスト の耐熱温度(条件により異なるが $160^{\circ} \mathrm{C}$ ～程度）を超える と,レジストが変形し加工精度が損なわれ，またレジス トのはく離性も低下する5)。つまり，大きなエッチング 速度でITOを加工するには, レジストの耐熱温度を超 えない程度の高温に基板温度をコントロールすることが 必要となる。この基板温度コントロール方法として, 基 板裏面と下部電極の隙間に He ガスを導入し, 基板と装 㯰間の熱伝導を大きくすることで基板の冷却効果を高め る He 冷却機構が多く用いられている101。図 $8 k \mathrm{He}$ 冷 却機構の効果を示す。

近年, 更なるエッチング速度の向上を目的として, RIE 方式ではプラズマ密度が低下する数 $\mathrm{mT}$ orr の高真 
空でも十分なプラズマ密度を確保でき, 大きなエッチン グ速度が期待できる高密度プラズマ源を用いたエッチン グ方式が検討されている。また，基板温度コントロール 特性を向上できる, 静電気による電極への基板吸着機構 の開発も行われている。

\section{3. 2 反応生成物の堆積}

ITO ドライエッチングの大きな課題として, 反応生 成物の堆積が上げられる ${ }^{8,10), 11 \text { 。 }}$ 。この反応生成物の堆積 は, (1)基板上への堆積と(2)内壁等の装置内部への堆積と の 2 つに大別できる。(1)の影響として，エッチング速度 と均一性の低下, レジストのはく離性の低下が問題とな る。ハロゲンガス系については, 反応生成物の蒸気圧が 高い HI ガス系の導入や基板温度コントロールを行うこ とで, 基板上への堆積物の少ないエッチングが可能と なっている。有機ガス系については，プラズマにより分 解生成された炭化物のレジスト上への堆積があり, 基板 温度コントロールだけでは十分な効果を得ることは難し く, 添加ガス, エッチング条件等で堆積物の低減を行っ ている。(2)の影響として, 量産時のエッチング特性の安 定性, 発塵, 装置トラブル, メンテナンス性等が問題と なる。対策として, 装置・配管全体を反応生成物が堆積 しない温度(ガス系にもよるが $100 \sim 150^{\circ} \mathrm{C}$ 程度) まで昇 温することが最も効果的であるが, 装置構造上の問題か ら完全に対応することは現実的に難しい。このため，定 期的なプラズマクリーニング等と組み合わせることで対 応する必要がある。装置構造の改善と効果的なプラズマ クリーニング法の開発が今後の課題である。

3. 3. 3 プラズマダメージ

ITO のエッチング速度を高め, 反応生成物の堆積を 抑制するために，イオン性を強めたドライエッチングが 要求されることを述べた。このイオン衝撃は, 同時にデ バイス特性へのダメージに蒰がる。具体的に, トランジ ス夕特性, 絶縁膜の絶縁特性の劣化などが上げられる。 例えば，図1(a)のような構造に適用した場合，トランジ

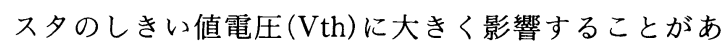
る3)。また, 図 1 (b)のような構造では, 層間絶縁膜中に 入り込んだイオンによる絶縁特性・信頼性への影響など を十分に評価する必要がある。これらのダメージについ てはデバイス構造, プロセスによりその影響が異なるた め，それぞれのデバイスに見合ったドライエッチング条 件の最適化が必要となる。

\section{ITO ドライエッチング技術の将来展望}

今後の液晶産業にとって, 大型ガラス基板を用いた多 